
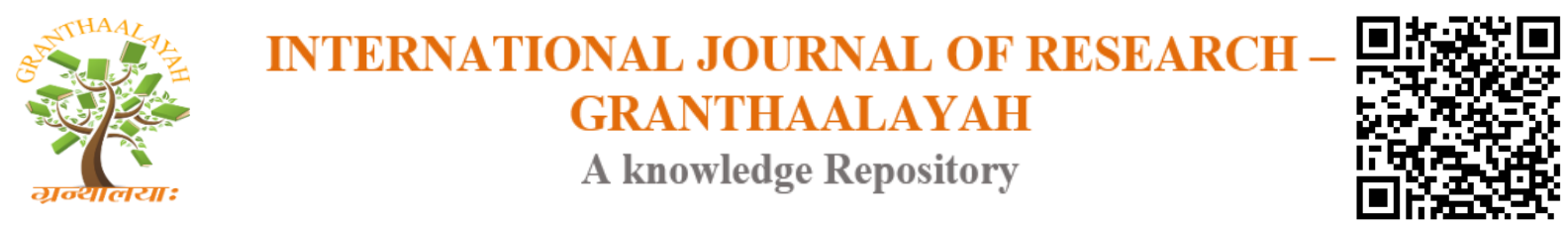

Management

\title{
FORECASTING INTERNATIONAL TOURISM DEMAND FOR ECUADOR
}

\author{
Jesser Roberto Paladines Amaiquema ${ }^{* 1}$, Lourdes Amaiquema Illesca ${ }^{2}$ \\ ${ }^{*}$ Department of Economics, Faculty of Business Studies, Universidad Técnica de Machala, \\ Ecuador \\ ${ }^{2}$ Department of Tourism, Faculty of Business Studies, Universidad Técnica de Machala, \\ Ecuador
}

\begin{abstract}
The international tourism demand for Ecuador was forecasted in this paper, with monthly data of foreign arrivals to Ecuador for the period 2000 to 2016. The Box-Jenkins model was applied, specifically the technique called ARIMA, in order to stablish the best fit to the foreign arrivals from the monthly period from January to June of 2017. According to results, the model was no statistically significant, residual correlations problem was found.

Keywords: Box-Jenkins; Ecuador; Tourism Demand.

Cite This Article: Jesser Roberto Paladines Amaiquema, and Lourdes Amaiquema Illesca. (2017). "FORECASTING INTERNATIONAL TOURISM DEMAND FOR ECUADOR." International Journal of Research - Granthaalayah, 5(8), 11-17. https:// doi.org/10.29121/granthaalayah.v5.i8.2017.2177.
\end{abstract}

\section{Introduction}

It is evidenced tourism help countries to grow, in the long run, as this sector stimulates many variables as, revenue, employment and investments.

Tourism provides foreign currencies and its effect is a positive impact on any economy, as increase local imports and keeps constant the foreign currency reserve level, but in the case of Ecuador that uses dollars, local tourism should be affected negatively if currency devaluation in the origin tourist country takes place.

According to the World Economic Forum Ecuador's tourism share of GDP is barely 5\% in comparison with the global tourism share of GDP that is about 9.5\%. Besides 1 of 11 employees are related with tourism worldwide, but in Ecuador is 1 of 20. The tourism service export in Ecuador is considered the third within the no oil revenue, but in has more tourist potential. 
Colombia, Peru and United States represent about $70 \%$ of total tourist arrival, and the rest $30 \%$ it is from the rest of the world. This study through some autoregressive moving average models forecasted the foreign arrivals to Ecuador for the period from January 2017 to June 2017, from monthly data from 2000 to 2016.

Some studies had used foreign tourist arrival as a proxy for Tourism, like (Shareef and McAleer, 2007; Lim and McAleer, 2000; Lin et al., 2011). Others have used tourist expenses (Li et al., 2006; Sheldon. 1993; Syriopoulos. 1995; Downward and Lumsdon. 2003).

Long and short run relationships between tourism and some macroeconomic variables are also studied, but some of these variables cannot be measured and most studies use proxy variables (Lim. 2000; Song et al., 2003), in tourism model studies, income and prices are the most explanatory variables used. Leisure tourism is considered as a luxury good, though this variable would be difficult to measure. Most studies rely on the use of nominal or real GDP or GDP per capita, as more income people have, they are likely to travel more. More specifically, some researchers have applied the industrial output index for proxy GDP as this can be measured monthly (Gonzales and Moral. 1995; Seo et al., 2009), these last two studies concluded that the index has a positive relationship with tourist arrivals.

Some specific index, like the relative hotel price index (Narayan, 2004) or others to measure the impact on tourist expenditure or cost of living in the destination country has been included, but this this kind of specific indices had not improved results from the relative price index (Martin and Witt, 1987). Tourism Price is calculated adjusting the variable by relative prices (Habibi and Rahim, 2009; Narayan, 2004).

The exchange rate is also taken into account (Halicioglu, 2010; Habibi and Rahim, 2009). According to (Artus, 1972) tourists respond quickly to changes in exchange rate instead of relative inflation, but (Martin and Witt, 1987) argued that the exchange rate alone does not capture impacts on tourism, for this, many studies use real exchange rate.

Transport and tourist accommodation is also used (Louca, 2006). Transportation is not yet measured to calculate the cost of transportation of tourists, some tourists travel by car using gasoline; meanwhile others use airplanes (Narayan, 2004). I use the variable oil price instead of transportation (Crouch, 1994). But it could show the multicolinearity problem as oil price and income present similar changes. (Lim, 1999); these issues can be fixed by using dummy variables.

Other variables have jointly been studied to measure the impact on tourism, variable like domestic consumption (Jackman and Lorde, 2010), number of people under the poverty line (Croes and Vanegas, 2008), industrial good imports (Nowak et al., 2007); direct foreign investment (Tang et al., 2007); exports and imports (Khan et al., 2005), also political unrest and recessions would affect the demand of tourism (Loeb, 1982).

All these studies have concluded there is a long run relationship, using ordinary least squares and advanced econometric methods like autoregressive lag models and error correction models, also they proved that tourism it is a relevant economic variable. 
Tourism it is related to some macroeconomic variables, as it is expressed above, there are many techniques to forecast, but one very popular, it is the econometric technique called the ARIMA model, developed by Box and Jenkins (1976).

Geurts, Buchman and Ibrahim, (1976); Petrevska, (2015); Bigović, (2012); Saayman and Saayman; (2010); Haridev, (2013); Baldigara and Mamula (2015); Akuno, et al (2015); Song, H., Wong, K., \& Chon, K. (2003) and Koutras et al (2016) used an ARIMA model to forecast the behaveviour of tourism in the short run.

\section{Materials and Methods}

It is evidenced tourism help countries to grow, in the long run, as this sector stimulates many variables as, revenue, employment and investments.

Tourism provides foreign currencies and its effect is a positive impact on any economy, as increase local imports and keeps constant the foreign currency reserve level (McKinnon, 1964) but in the case of Ecuador that uses dollars, local tourism should be affected negatively if currency devaluation in the origin tourist country takes place.

According to the World Economic Forum Ecuador's tourism share of GDP is barely 5\% in comparison with the global tourism share of GDP that is about 9.5\%. Besides 1 of 11 employees are related with tourism worldwide, but in Ecuador is 1 of 20. The tourism service export in Ecuador is considered the third within the no oil revenue, but in has more tourist potential.

Colombia, Peru and United States represent about $70 \%$ of total tourist arrival, and the rest $30 \%$ it is from tge rest of the world. This study through some autoregressive moving average models forecasted the foreign arrivals to Ecuador for the period from January 2017 to June 2017, from monthly data from 2000 to 2016.

Some studies had used foreign tourist arrival as a proxy for Tourism, like (Shareef and McAleer, 2007; Lim and McAleer, 2000; Lin et al., 2011). Others have used tourist expenses (Li et al., 2006; Sheldon. 1993; Syriopoulos. 1995; Downward and Lumsdon. 2003).

Long and short run relationships between tourism and some macroeconomic variables are also studied, but some of these variables cannot be measured and most studies use proxy variables (Lim. 2000; Song et al., 2003), in tourism model studies, income and prices are the most explanatory variables used. Leisure tourism is considered as a luxury good, though this variable would be difficult to measure. Most studies rely on the use of nominal or real GDP or GDP per capita, as more income people have, they are likely to travel more. More specifically, some researchers have applied the industrial output index for proxy GDP as this can be measured monthly (Gonzales and Moral. 1995; Seo et al., 2009), these last two studies concluded that the index has a positive relationship with tourist arrivals.

Some specific index, like the relative hotel price index (Narayan, 2004) or others to measure the impact on tourist expenditure or cost of living in the destination country has been included, but this this kind of specific indices had not improved results from the relative price index (Martin 
and Witt, 1987). Tourism Price is calculated adjusting the variable by relative prices (Habibi and Rahim, 2009; Narayan, 2004).

The exchange rate is also taken into account (Halicioglu, 2010; Habibi and Rahim, 2009). According to (Artus, 1972) tourists respond quickly to changes in exchange rate instead of relative inflation, but (Martin and Witt, 1987) argued that the exchange rate alone does not capture impacts on tourism, for this, many studies use real exchange rate.

Transport and tourist accommodation is also used (Louca, 2006). Transportation is not yet measured to calculate the cost of transportation of tourists, some tourists travel by car using gasoline; meanwhile others use airplanes (Narayan, 2004). I use the variable oil price instead of transportation (Crouch, 1994). But it could show the multicolinearity problem as oil price and income present similar changes. (Lim, 1999); these issues can be fixed by using dummy variables.

Other variables have jointly been studied to measure the impact on tourism, variable like domestic consumption (Jackman and Lorde, 2010), number of people under the poverty line (Croes and Vanegas, 2008), industrial good imports (Nowak et al., 2007); direct foreign investment (Tang et al., 2007); exports and imports (Khan et al., 2005), also political unrest and recessions would affect the demand of tourism (Loeb, 1982).

All these studies have concluded there is a long run relationship, using ordinary least squares and advanced econometric methods like autoregressive lag models and error correction models, also they proved that tourism it is a relevant economic variable.

Tourism it is related to some macroeconomic variables, as it is expressed above, there are many techniques to forecast, but one very popular, it is the the econometric technique called the ARIMA model, developed by Box and Jenkins (1976).

Geurts, Buchman and Ibrahim, (1976); Petrevska, (2015); Bigović, (2012); Saayman and Saayman; (2010); Haridev, (2013); Baldigara and Mamula (2015); Akuno, et al (2015); Song, H., Wong, K., \& Chon, K. (2003) and Koutras et al (2016) used an ARIMA model to forecast the behaveviour of tourism in the short run.

\section{Results and Discussions}

\subsection{Unit Root Test}

Dickey and Fuller (1981), have computed the critical values of the t-statistic based on Monte Carlo simulations. This t-statistic is known as the Dickey-Fuller (DF) test, which does not follow the usual t-distribution. DF test is estimated using three different equations: With intercept, prone and Intercept and random walk). In each case, the null hypothesis is that there is a unit root. (Agung GN, 2009) The DF tests assume that the errors are independent and have a constant variance. (Enders, 2015). 
Variable was subjected to a unit root test. Both the Dickey-Fuller Augmented Test (ADF) and the Phillips-Perron (PP) test (Phillips and Perron, 1988) showed serie had a unit root in levels, but at first difference it did not have unit root either intercept or with tendency and intercept at $1 \%$.

The ARIMA model is applied to data, assuming data is not stationary, as PP and DF tests determined. According to results the best model with the lowest AIC was ARIMA $(5,1,0)$. Coefficients are showed below.

Table 1: ARIMA Model $(5,1,0)$ with drift, Author's

\begin{tabular}{llllll}
\hline \multicolumn{1}{c}{ ar1 } & \multicolumn{1}{c}{ ar2 } & ar3 & ar4 & \multicolumn{1}{c}{ ar5 } & \multicolumn{1}{c}{ drift } \\
\hline-0.5401 & -0.7645 & -0.594 & 0.7245 & -0.4 & 365.1601 \\
0.0646 & 0.0553 & 0.0648 & 0.0548 & 0.0659 & 162.4712 \\
\hline
\end{tabular}

\subsection{Diagnostic Test}

Autocorrelation problem in residuals are a common issue in no stationary data in ARIMA models, results suggest that the model $(5,1,0)$ with drift, has autocorrelation problem. According to the Box-Lung test and the ACF and PACF graphs. The P-value of the Box-Lung test was 0.00, conluding there is a autocorrelation problem in calculated results. The graphs tests are shown below, these two tests are in agree with the Box-Lung test.

$(5,1,0)$ Model Residuals
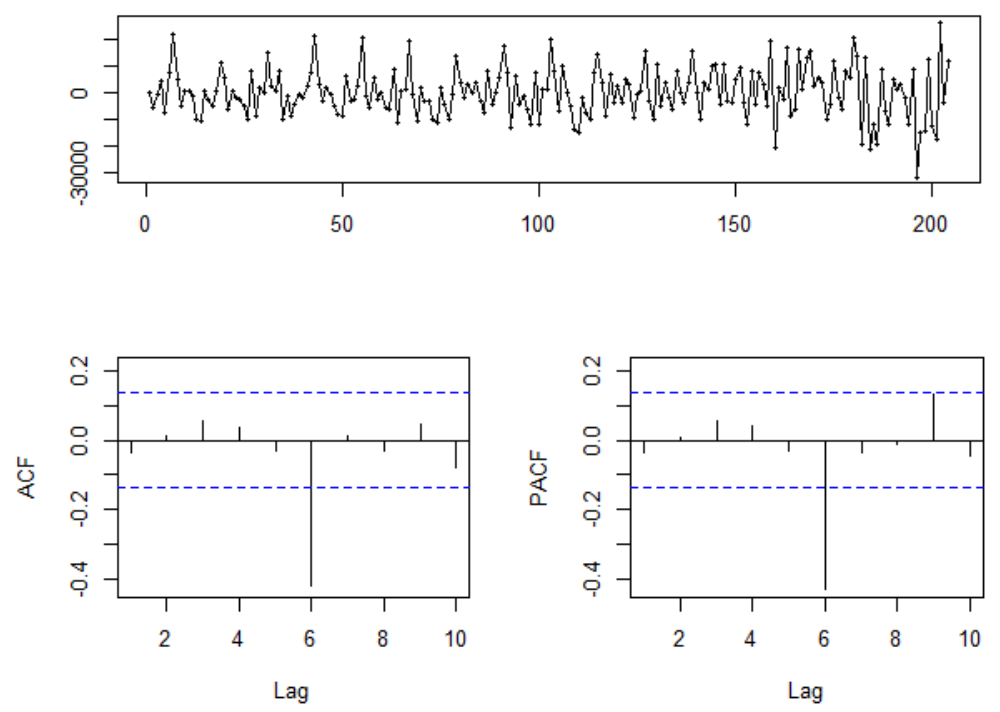

Figure 1: ACF and PACF test, Author's

\section{Conclusion}

The long run economic relationship of the tourism demand model for Ecuador was carried out in (Paladines, 2017), using variables as the number of arrivals, the income of the origin country of the tourist, proxied by industrial or production index, tourism price, it was concluded that the 
more income, more leisure expenditure for tourism (Gonzales and Moral, 1995; Seo, et al., 2009; Halicioglu, 2010; Song et al., 2003).

In this paper the model ARIMA was applied to the number of arrivals, in order to be able to do a short run or a long run forecast for tourism. The model chosen was ARIMA $(5,1,0)$. The model developed showed itself no statistically significant, as results suggested autocorrelation problem, any forecast operation will be invalid, as the assumption of autocorrelation is violated.

\section{References}

[1] Agung, G. N.. Time Series Data Analysis Using EViews. Stat Papers, 52(2), 2009, pp.497-499. DOI: http://dx.doi.org/10.1007/s00362-009-0281-1

[2] Artus, J. An Econometric Analysis of International Travel (Analyse économétrique des voyages internationaux). Staff Papers (International Monetary Fund), 19(3), 1972, 579-614. DOI: http://dx.doi.org/10.2307/3866418

[3] Croes, R., \& Vanegas, M.. Cointegration and Causality between Tourism and Poverty Reduction. Journal of Travel Research, 47(1), 2008, 94-103.

DOI: https://doi.org/10.1177/0047287507312429

[4] Crouch, G. The Study of International Tourism Demand: A Review of Findings. Geoffrey I. Crouch, 33(1), 1994, 12-23. DOI: https://doi.org/10.1177/004728759403300102

[5] Dickey, D., \& Fuller, W. Distribution of the Estimators for Autoregressive Time Series With a Unit Root. Journal of the American Statistical Association. 74(366), 1979, p.427-431. DOI: http://dx.doi.org/10.2307/2286348

[6] Dickey, D., \& Fuller, W. Likelihood ratio statistics for autoregressive time series with a unit root. Econometrica 49(4), 1981, pp.1057-1072. DOI: http://dx.doi.org/10.2307/1912517

[7] Downward, P., \& Lumsdon, L. Beyond the Demand for Day-Visits: An Analysis of Visitor Spending. Tourism Economics, 9(1), 2003, 67-76.

DOI: https://doi.org/10.5367/000000003101298277

[8] Enders, W. Applied Econometric Time Series (4ta.ed.). Chichester, West Sussex: Jhon Wiley \& Sons. 2015

[9] Engle, R., \& Granger, C. Co-Integration and Error Correction: Representation, Estimation, and Testing. Econometrica, 55(2), 1987, p.251. DOI: http://dx.doi.org/10.2307/1913236.

[10] Habibi, F., \& Rahim, K. A Bound Test Approach to Cointegration of Tourism Demand. American Journal of Applied Sciences, 6(11), 2009, 363-382.

DOI: https://doi.org/10.3844/ajassp.2009.1924.1931

[11] Halicioglu, F. An Econometric Analysis of the Aggregate Outbound Tourism Demand of Turkey. Tourism Economics, 16(1), 2010, 83-97. DOI: https://doi.org/10.5367/000000010790872196

[12] INEC. (2017). Instituto Nacional de Estadísticas y Censos.

[13] Jackman, M., \& Lorde, T. (2010). On the Relationship between Tourist Flows and Household Expenditure in Barbados: A Dynamic OLS Approach. Economics Bulletin, 30(1), 472-481. Retrieved from http://www.accessecon.com/Pubs/EB/2010/Volume30/EB-10-V30-I1-P42.pdf

[14] Khan, H., Toh, R., \& Chua, L. Tourism and Trade: Cointegration and Granger Causality Tests. Journal of Travel Research, 44(2), 2005, 171-176.

DOI: https://doi.org/10.1177/0047287505276607

[15] Li, G., Song, H., \& Witt, S. Time varying parameter and fixed parameter linear AIDS: an application to tourism demand forecasting. International journal of forecasting, 22(1), 2006, 5771. DOI: https://doi.org/10.1016/j.ijforecast.2005.03.006

[16] Lim, C. A Meta-Analytic Review of International Tourism Demand. Journal of Travel Research, 37(3), 1999, 273-284. DOI: https://doi.org/10.1177/004728759903700309 
[17] Lim, C., \& McAleer, M.A seasonal analysis of Asian tourist arrivals to Australia. Applied Economics, 32(4), 2000, 499-50. DOI: http://dx.doi.org/10.1080/000368400322660

[18] Lin, H.-L., Liu, L.-M., Tseng, Y.-H., \& Su, Y.-W. Taiwan's international tourism: a time series analysis with calendar effects and joint outlier adjustments. International Journal of Tourism Research, 13(1), 2011, 1-16. DOI: http://dx.doi.org/10.1002/jtr.779

[19] Loeb, P. D. International travel to the United States: An econometric evaluation. Annals of Tourism Research, 9(1), 1982, 7-20. DOI: http://dx.doi.org/10.1016/0160-7383(82)90031-7

[20] Louca, C. Income and Expenditure in the Tourism Industry: Time Series Evidence from Cyprus. 12(4), 2006, 603-617. DOI: https://doi.org/10.5367/000000006779319963

[21] Martin, C., \& Witt, S. Tourism demand forecasting models: Choice of appropriate variable to represent tourists' cost of living, Tourism Management. Tourism Management, 8(3), 2007, 233246. DOI: http://dx.doi.org/10.1016/0261-5177(87)90055-0

[22] Nowak, J.-J., Sahli, M., \& Cortés-Jiménez, I. Tourism, Capital Good Imports and Economic Growth: Theory and Evidence for Spain. Tourism Economics, 13(4), 2007, 515-536. DOI: https://doi.org/10.5367/000000007782696113

[23] Pesaran, H., Shin, Y., \& and Smith, R. Bounds testing approaches to the analysis of level relationships. Journal of Applied Econometrics, 16(3), 2001, 289--326.

DOI: https://doi.org/10.1002/jae.616

[24] Pesaran, H., Shin, Y., \& and Smith, R.. Testing for the Existence of a Long-run Relationship. Cambridge Working Papers in Economics 9622, Faculty of Economics, University of Cambridge. 1986

[25] Phillips, P., \& Perron, P. Testing for a unit root in time series regression. Biometrika, 75(2), pp. 1988, 335-346. DOI: https://doi.org/10.1093/biomet/75.2.335

[26] Seo, J., Park, S., \& Yu, L. The analysis of the relationships of Korean outbound tourism demand: Jeju Island and three international destinations. Tourism Management, 30(4), 2009, 530-543. DOI: http://dx.doi.org/10.1016/j.tourman.2008.10.013

[27] Sheldon, P. Forecasting Tourism: Expenditures versus Arrivals. Journal of Travel Research, 32(1), 1993, 13-20. DOI: https://doi.org/10.1177/004728759303200103

[28] Song, H., Wong, K., \& Chon, K. Modelling and forecasting the demand for Hong Kong tourism. International Journal of Hospitality Management, 22(4), 2003, 435-451. DOI: http://dx.doi.org/10.1016/S0278-4319(03)00047-1

[29] Syriopoulos, T. C. A dynamic model of demand for Mediterranean tourism. International Review of Applied Economics, 9(3), 1995, 318-336. DOI: http://dx.doi.org/10.1080/758537633

[30] Tang, S., Selvanathan, E., \& Selvanathan, S. The Relationship between Foreign Direct Investment and Tourism: Empirical Evidence from China. Tourism Economics, 13(1), 2017, 2539. DOI: https://doi.org/10.5367/000000007779784498

[31] WTO. World Tourism Organization. 2017, Retrieved from de http://www2.unwto.org

*Corresponding author.

E-mail address: jesserpaladines@ gmail.com 